\title{
産業界から見た生物多様性条約の下での デジタル配列情報の議論について
}

井上歩

\section{はじめに}

1993年 12 月に発効した生物多様性条約 ${ }^{1}$ (以

下、CBD）は、（i）生物多様性の保全、(ii) 生物 多様性の構成要素の持続可能な利用、（iii）遺伝 資源の利用から生ずる利益の公正かつ衡平な配 分、の三つを目的とする条約である。また、三 つ目の目的に関連し、遺伝資源へのアクセスと 利益配分 (Access and Benefit-sharing: ABS) に関する国際的な枠組みを定めているのが、 2014年 10 月に発効した名古屋議定書 ${ }^{2}$ である。

本特集で紹介されているように、現在、この $\mathrm{CBD}$ 及び名古屋議定書の下で、塩基配列情報等 の情報の取り扱いに関する議論が起きている。 本稿では、この議論に対するバイオインダスト JBA）をはじめとする産業関連団体の見解を紹 介したい。

なお、現在この議論では、塩基配列情報等 リー協会（Japan Bioindustry Association：以下、

含むのか）等については、まだコンセンサスが 得られていない。

\section{ABS の基本原則}

以下に述べる産業界の見解とも関連するので、 まずCBD及び名古屋議定書の下での $\mathrm{ABS}$ 基 本原則について説明しておきたい。

遺伝資源へアクセス（遺伝資源を取得）する 際には、遺伝資源提供国の国内法令等に従い、 (1)当該国の事前同意（prior informed consent： PIC) を得るとともに、(2)遺伝資源の提供者と、 その利用目的や利用条件、利益配分等に関する 契約（mutually agreed terms：MAT）を結ぶこ とが、 $\mathrm{CBD}$ 及び名古屋議定書の下での $\mathrm{ABS}$ 基 本原則である（図1）。

現在、CBD及び名古屋議定書の下で行われて いるDSIに関する議論というのは、この ABSの対 象にDSIを含めるべきであるという議論である。

の情報に対し「遺伝資源に関するデ ジタル配列情報」(Digital Sequence Information on Genetic Resources) (以 下、DSI）という用語が用いられて いる。本稿でもこの用語を用いるが、 国際交渉の場においても、この用語 が適切であるのかや、定義や適用範 囲（塩基配列やアミノ酸配列等何を

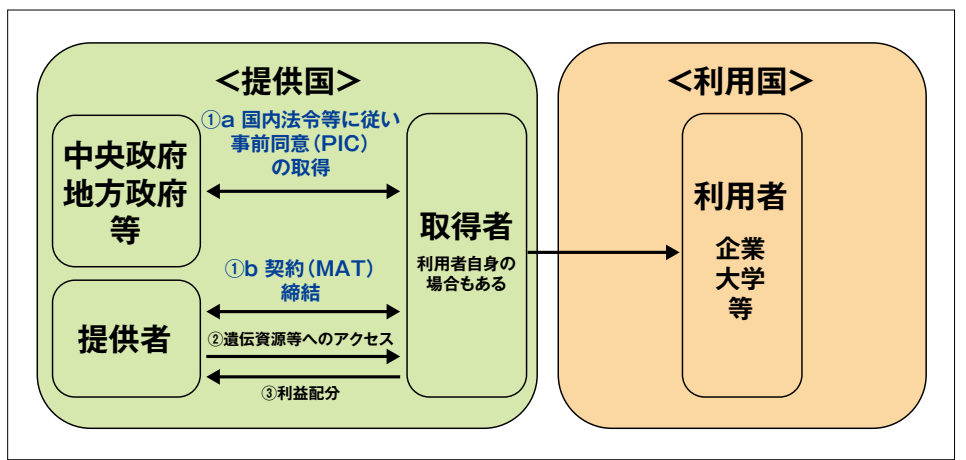

図1 ABSの基本原則 
なお、ここでいう利益配分の「利益」(benefit) とは、金銭的な profitだけではなく、非金銭的な 「遺伝資源の提供者と利用者のためになる物や 事」などを含む広範囲なものである。

\section{バイオインダストリー協会の見解}

このDSIの議論に関連し、2017年 9 月、CBD 事務局から締約国やその他関係機関等に対し、 「DSIの使用が、CBD 及び名古屋議定書の目的に 対し、どのように関係し得るか」ということに ついて、見解や関連情報を提出するよう要請が あった。これを受け、14の締約国、1つの非締約 国、その他 40 の関係機関等から、見解等が提出 された ${ }^{3}$ 。

これにJBAも見解 ${ }^{4}$ を提出したので、その概要 を以下に紹介する。

\section{2-1ＤSIとCBD及び名古屋議定書との関係}

CBD 及び名古屋議定書の下で、「遺伝資源」は、 「現実の又は潜在的な価值を有する遺伝素材をい う」と定義されており、その「遺伝素材」は、「遺 伝の機能的な単位を有する植物、動物、微生物 その他に由来する素材（material）をいう」と定 義されている。私たちは、この定義から「遺伝 資源」は有形の素材であり、無形のDSIは「遺 伝資源」に該当せず、そもそも ABSの直接の対 象（PIC手続きの対象）ではないと考えている。

しかしその一方、利益配分を含め、アクセス された遺伝資源を利用して得られたDSIの取り 扱いに関しては、遺伝資源の提供者と利用者の

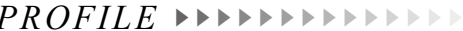

井上 歩 (いのうえ あゆむ)

- 一般財団法人バイオインダストリー協会 生物資源総合研究所所長

専門 生物多様性条約及び名古屋議定書 の下での遺伝資源へのアクセスと利 益配分

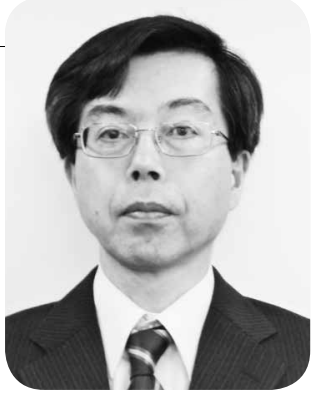

間の契約（MAT）によってカバーされ得る。こ のためアクセスされた遺伝資源を利用して得ら れたDSIに関する利益配分は、今現在でもCBD 及び名古屋議定書から除外されていないという のが私たちの立場である。

\section{2-2 DSIの使用とCBD及び名古屋議定書の目 的との関係}

また、「DSIの使用が、CBD及び名古屋議定書 の目的に対し、どのように関係し得るか」とい うことについては、次のような情報提供を行っ た。

\section{（i）生物多様性の保全}

生物多様性を保全するためには、まずその現 状を把握する必要がある。従来、生物多様性の モニタリングは、形態的な特徴に基づいた目視 による野外調查に頼ってきた。しかしながら、 そのような方法は、形態的な特徴を識別するた めの高度な専門性に依存し、多くのコスト、労力、 時間を要し、さらには、生物又は環境に対して 侵襲的になる場合があった。このため、生物多 様性の保全に有用な情報を得るのは容易ではな かった。

これに対し、最近では、塩基配列情報を利用 したDNAバーコーディングやDNAメタバー コーディングなどの新しい技術が開発され、生 物多様性のモニタリングに活用されている。こ 
れらのアプローチは、形態的な特徵を識別する ための高い専門性に依存せず、従来の方法に比 ベ、コスト、労力、時間が削減できることから、 生物多様性の保全に必要な情報をより適切に得 ることができる。このように、DSIが生物多様性 の保全に貢献することが期待される。

\section{（ii）生物多様性の構成要素の持続可能な利用}

上述のDNAバーコーディングやDNAメタ バーコーディングに基づく生物多様性のモニ夕 リングによれば、その費用対効果のために、あ る地域の生物多様性をこれまで以上に定期的に モニタリングすることができる。これにより、 生物多様性の構成要素の変化に関し情報を得る ことができ、持続可能な利用のためのより適切 な計画を策定し実施することが可能となる。

また、DNAマーカーを用いて、野生種と家畜 種又は栽培種との区別や、同じ種の生息地の判 別が可能性となる。これにより、例えば、市場 に供給された薬用植物や木材をモニタリングす ることにより、野生の薬用植物の過剩採取や特 定地域での木材の過剩伐採を防止することがで きる。

このように、DSIは生物多様性の構成要素の 持続可能な利用にも貢献し得る可能性がある。

\section{（iii）利益配分}

先に述べたように、アクセスされた遺伝資源 を利用して得られたDSIに関する利益配分は、 遺伝資源の提供者と利用者の間の契約（MAT） によってカバーされ得る。
また、DSIの多くは、オープンに利用可能な データベースに登録されており、生物多様性の 保全及びその構成要素の持続可能な利用を含む あらゆる目的のために、どの国の誰でもが、そ のデータベースに自由にアクセスし利用するこ とができる。これも利益配分の一つである。

\section{2-3 DSIのイノベーションに対する役割}

現代の生命科学とバイオテクノロジーの研究 開発においてDSIは不可欠であり、我々の国際 社会の主要分野（例えば、健康、食料／農業、 環境）におけるイノベーションは、データベー スにあるDSIへのオープンなアクセスによって 支えられている。これに対し規制上の制約を設 けることは、生物多様性の保全及びその構成要 素の持続可能な利用のみならず、人類の活動全 体に悪影響を及ぼすことになるので、決してそ のようなことを引き起こしてはならない。

以上が、私たちJBAの見解である。

\section{他の産業関連団体等の見解}

先の見解提出に際し、JBAの他にも、国際商 業会議所（International Chamber of Commerce： ICC）や日本製薬工業協会等、多くの産業関連団 体が見解等を提出した。ここでは、その一つ一 つについては触れないが、それらの見解を集約 すると、私たちと同様にDSIを ABS規制の対象 とすることには反対の立場であり、その理由とし ては、次のようなものが挙げられていた ${ }^{5}$ 
・DSIへのオープンなアクセスと自由な使用 を妨げてはならない。

・DSIをデータベースに登録し、自由に使っ てもらうことが公正かつ衡平な利益配分で ある。

・DSIは、CBD及び名古屋議定書の下での ABS 規制の対象ではない。

・DSIを ABS規制の対象とすることは、法的 不確実性と過度な負担による遵守困難性を もたらすことになる。

・現在のABS システムが機能していないこと の解決策にはならない。

・単なる生物多様性条約締約国会議 (COP) の決定事項とすべきではない。

・科学知識が国の政府によって規制されるこ とは、科学研究の独立性を脅かす問題につ ながる恐れがある。

また、ICCは、2018年7月に開催されたCBD の第 22 回科学技術助言補助機関会合に際し、 DSIを ABS 規制の対象とすることに反対する “Joint Stakeholder Statement”6を発表した。これ には、公共及び民間機関、学術及び科学機関、デー タレポジトリならびにコレクションなど、 $66 も$ の国際／地域／各国機関が名を連ね、日本から は、日本製薬工業協会、日本酵素協会、JBAが 参加した。

\section{おわりに}

JBA は、CBD及び名古屋議定書の目的を支持
し、これらの目的の適切な実施に積極的に貢献 し、これからも貢献していく所存である。その ためには、ABSに関する法的確実性と過度な負 担を伴わない遵守可能な枠組みが不可欠である が、DSIの導入は、これらを損なう恐れがある。

また、イノベーションは、データベースにあ るDSIへのオープンアクセスによって支えられ ており、これに対し規制上の制約を設けること は、生物多様性の保全及びその構成要素の持続 可能な利用のみならず、人類の全ての活動に悪 影響を及ぼすことになる。

このため、DSIを ABS規制の対象とすること については、誤った結論に至らぬよう、関係者 が良好な関係の下に協力し、事実に基づきより 広い見地に立ち、種々の条件を勘案して慎重に 検討していかなければならない。

注

$1 \mathrm{CBD}$ 事務局：(英語正文) https://www.cbd.int/convention/ text/

環境省：(公定訳) http://www.biodic.go.jp/biolaw/jo_hon.html

2 CBD 事務局 : (英語正文) https://www.cbd.int/abs/text/ default.shtml

外務省：(公定訳) https://www.mofa.go.jp/mofaj/ files/000236481.pdf

3 CBD事務局 : https://www.cbd.int/abs/dsi-gr/ahteg. shtml\#submissions

4 CBD 事務局 : “Views of Japan Bioindustry Association (JBA) on the issues of Digital Sequence Information on Genetic Resources" https://www.cbd.int/abs/DSI-views/JBA-DSI.pdf

5 JBA生物資源総合研究所：「平成29年度我が国におけるデー 夕駆動型社会に係わる基盤整備（生物多様性総合対策事業） 委託事業報告書」p.304 http://www.mabs.jp/archives/reports/ index_h29.html

6 ICC : "Promoting sustainable use and conservation of biodiversity through open exchange of Digital Sequence Information" https://iccwbo.org/publication/promotingsustainable-use-conservation-biodiversity-open-exchangedigital-sequence-information/ 